\title{
Effect of Substitution of Fermented Kapok Seed (Ceiba petandra) to Soybean Meal on Production and Egg Quality from Native Laying Hens
}

\author{
Erman Syahruddin $^{1}$, Rita Herawaty ${ }^{2}$ and Azhar Ibrahim ${ }^{1}$ \\ 1. Department of Animal Production, Faculty of Animal Sciences, Andalas University, Kampus Limau Manis, Padang 25163, \\ Indonesia \\ 2. Department of Animal Nutrition and Feed Technology, Faculty of Animal Sciences, Andalas University, Kampus Limau Manis, \\ Padang 25163, Indonesia
}

\begin{abstract}
This study aimed to determine the level of use of fermented kapok seed to substitute $100 \%$ soybean meal in native laying hen rations without adverse effect on laying hen production. Two hundred and forty laying hens aged 20 weeks were used in this experiment. The completely randomized design was assigned with six treatments to replace $0,20 \%, 40 \%, 60 \%, 80 \%$ and $100 \%$ of soybean meal with fermented kapok seed with four replications. The variables measured were feed intake, feed conversion and income over feed cost (gross profit), as well as variables related to egg production (hen day production and egg weight), thickness of eggshell and yolk color index for quality of eggs. Data were analyzed statistically using analysis of variance (ANOVA), and if the result shows a marked influence, it will be followed by Duncans test (DMRT). The results showed that the performance of laying hen had not been affected significantly by substituting soybean meal with fermented kapok seed. Feed intake, feed conversion and egg production is not influenced either. In summary, the use of fermented kapok seed to substitute soybean meal in the ration can be up to $100 \%$ in the diet of laying chicken.
\end{abstract}

Key words: Fermented kapok seed (Ceiba petandra), substitution, hen day production, native laying hen.

\section{Introduction}

Soybean meal is one of the feed material source of vegetable protein component of poultry rations, which contains high protein and complete amino acids than other vegetable feed ingredients, although on the other hand, their availability was sometimes limited. Amount of soybean meal required is always increasing along with the development of poultry farming. The need for more soybean meal is met from imports almost $100 \%$, which is approximately 1.96504 million tons in 2013 [1]. In order to reduce dependence on imported feed ingredients, such as soybean meal, it is necessary to find the alternative raw material feed. One thing that has not been widely

Corresponding author: Erman Syahruddin, professor, research field: poultry production. used is the seed of kapok tree (Ceiba petandra), which is an agricultural waste. This plant has high adaptability and can grow to a height of $1,500 \mathrm{~m}$. According to the Central Bureau of Statistics [1], there are extensive rubber plantations in Indonesia about 13,896,212 ha. Each one hectare kapok plantation planted 200-300 trees.

The low nutrient content and the presence of anti-nutritional substances in the diet resulted that its use is not maximized. Kapok seed contained from $27.40 \%$ to $18.62 \%$ crude protein, $11.57 \%$ fat, $1,853.42$ $\mathrm{kcal} / \mathrm{kg}$ to $2,410.51 \mathrm{kcal} / \mathrm{kg}$ metabolizable energy, $51.33 \%$ to $69.15 \%$ nitrogen retention and $16.81 \%$ to 19.58 crude fiber [2]. According to Zahirma [3] and Sihombing [4], metabolizable energy of kapok seed are about 4,627 kcal/kg. Kapok seed also contain various amino acids, such as aspartic acid 9.50\%, 
glutamic acid $12.41 \%$, lysine $2.30 \%$, arginine $7.18 \%$, methionine $0.87 \%$ and trionin $2.43 \%$ of the total protein [5]. The main obstacle in the use of the kapok seed as animal feed is the high levels of cyanide (HCN). According to Lauw et al. [6], HCN content of the kapok seed of fresh is $325 \mathrm{mg} / 100 \mathrm{~g}$. According to Syahruddin and Herawaty [7], HCN content of the kapok seed can be reduced or eliminated by the process of storage, extraction, drying and soaking in water or boiling. It is said that the kapok was soaked for $24 \mathrm{~h}$ can reduce the levels of HCN, while according to Toh and Chia [8], kapok seeds are boiled at $160{ }^{\circ} \mathrm{C}$ temperature can eliminate toxins HCN. Syahruddin and Herawaty [9] showed that the kapok seed of fresh kapok supplied in the diet of broiler chickens in excess of 9\% can reduce weight gain and feed intake. To anticipate processing needs to be done so that the quality of the kapok seed can be increased. Way that can be used is the fermentation technology of the kapok seed with microbe (Trichoderma harzianum), which is able to increase the percentage of crude protein to $33.85 \%$, according Syahruddin and Herawaty [9] and Chalal [10]. This study aimed to determine the utilization of kapok seed fermented with Trichoderma harzianum on biological test. Fermented kapok seeds will be used as a substitute as much as $0,20 \%, 40 \%, 60 \%$, $80 \%$ and $100 \%$ protein soybean meal in rations of native layers.

\section{Materials and Methods}

Biological experiments were conducted to determine the effect of a $100 \%$ replacement of soybean meal protein with fermented kapok seed in rations of native layers. The study was conducted at the Faculty of Animal Science, Andalas University, Padang.

\subsection{Materials and Treatments}

The experiment used 240 native layers aged 20 weeks for eight weeks in the cage-shaped battery. Ration of research was prepared by adding fermented kapok seed. Ration was composed as iso protein and iso energy.

The treatments were as follows:

$\mathrm{R}_{0}$ : fermented kapok seed much as 0 (control diet or without replacement of soybean meal);

$\mathrm{R}_{1}$ : replacement of $20 \%$ protein soybean meal with fermented kapok seed;

$\mathrm{R}_{2}$ : replacement of $40 \%$ protein soybean meal with fermented kapok seed;

$\mathrm{R}_{3}$ : replacement of $60 \%$ protein soybean meal with fermented kapok seed;

$\mathrm{R}_{4}$ : replacement of $80 \%$ protein soybean meal with fermented kapok seed;

$\mathrm{R}_{5}$ : replacement of $100 \%$ protein soybean meal with fermented kapok seed.

The diet composition for each animal can be seen in Table 1, whereas the content of nutrients and metabolic energy in Table 2.

Table 1 Composition of rations for native layers (CP 17\% and ME 2,800 kcal $/ \mathrm{kg}$ ).

\begin{tabular}{lllllll}
\hline Ingredient & \multicolumn{5}{c}{ Percentage } \\
\cline { 2 - 7 } & $\mathrm{R}_{0}$ & $\mathrm{R}_{1}$ & $\mathrm{R}_{2}$ & $\mathrm{R}_{3}$ & $\mathrm{R}_{4}$ & $\mathrm{R}_{5}$ \\
\hline Corn & 50.00 & 49.13 & 48.26 & 47.39 & 46.52 & 45.65 \\
Soybean meal & 20.00 & 16.00 & 12.00 & 8.00 & 4.00 & 0.00 \\
Fermented kapok seed & 0.00 & 5.87 & 11.74 & 17.61 & 23.48 & 29.35 \\
Fine rice bran & 15.50 & 14.50 & 13.50 & 12.50 & 11.50 & 10.50 \\
Fish meal & 6.00 & 6.00 & 6.00 & 6.00 & 6.00 & 6.00 \\
Bone meal & 1.50 & 1.50 & 1.50 & 1.50 & 1.50 & 1.50 \\
Flour shells & 4.00 & 4.00 & 4.00 & 4.00 & 4.00 & 4.00 \\
Coconut oil & 2.50 & 2.50 & 2.50 & 2.50 & 2.50 & 2.50 \\
Feed additive & 0.50 & 0.50 & 0.50 & 0.50 & 0.50 & 0.50 \\
\hline Total & 100 & 100 & 100 & 100 & 100 & 100 \\
\hline
\end{tabular}


Table 2 The nutrient content of rations.

\begin{tabular}{lllllll}
\hline Components & $\mathrm{R}_{0}$ & $\mathrm{R}_{1}$ & $\mathrm{R}_{2}$ & $\mathrm{R}_{3}$ & $\mathrm{R}_{4}$ & $\mathrm{R}_{5}$ \\
\hline Crude protein (\%) & 17.68 & 17.59 & 17.49 & 17.40 & 17.31 & 17.21 \\
Fat (\%) & 3.91 & 3.90 & 3.89 & 3.88 & 3.87 & 3.86 \\
Crude fiber (\%) & 4.78 & 5.17 & 5.56 & 5.95 & 6.34 & 6.73 \\
Ca (\%) & 3.03 & 3.01 & 2.99 & 2.92 & 2.90 & 2.88 \\
P total (\%) & 0.68 & 0.69 & 0.70 & 0.71 & 0.72 & 0.73 \\
ME (kcal/kg) & $2,842.80$ & $2,840.30$ & $2,837.80$ & $2,835.30$ & $2,832.80$ & $2,830.30$ \\
Methionine (\%) & 0.296 & 0.295 & 0.293 & 0.291 & 0.290 & 0.289 \\
Lysine (\%) & 1.11 & 1.053 & 0.99 & 0.93 & 0.87 & 0.82 \\
\hline
\end{tabular}

Poultry Laboratory, Faculty of Animal Husbandry, Andalas University, 2013 [2]. ME: metabolizable energy.

Table 3 Average feed consumption, day egg production of hen, egg weight and feed conversion of laying hen per week.

\begin{tabular}{lllll}
\hline Treatments & $\begin{array}{l}\text { Feed consumption } \\
\text { (g/head/week) }\end{array}$ & $\begin{array}{l}\text { Day egg production of } \\
\text { hen }(\%)\end{array}$ & $\begin{array}{l}\text { Egg weight } \\
\text { (g/head/week) }\end{array}$ & Feed conversion ratio \\
\hline $\mathrm{R}_{0}$ & 556.30 & 33.76 & 98.76 & 5.41 \\
$\mathrm{R}_{1}$ & 562.36 & 34.09 & 101.30 & 5.34 \\
$\mathrm{R}_{2}$ & 566.65 & 33.06 & 102.23 & 5.33 \\
$\mathrm{R}_{3}$ & 569.05 & 33.74 & 99.84 & 5.48 \\
$\mathrm{R}_{4}$ & 565.05 & 33.10 & 96.60 & 5.61 \\
$\mathrm{R}_{5}$ & 562.89 & 32.38 & 96.48 & 5.60 \\
\hline Average & 563.72 & 33.36 & 99.20 & 5.46 \\
\hline
\end{tabular}

\subsection{Data Analysis}

All data were analyzed using analysis of variance (ANOVA) of a completely randomized design according to Steel and Torrie [11]. Differences between treatments tested with Duncan's multiple range test (DMRT).

\section{Results and Discussion}

3.1 Effect of Treatments on Consumption, Day Egg Production of Hen, Egg Weight and Feed Conversion on Native Layers

The average feed consumption, day egg production of hen, egg weight and feed conversion per head per week during the study was presented in Table 3.

Results of analysis of variance showed that the substitution of soybean meal protein with protein from fermented kapok seed to $100 \%$ in the diet of native laying hen had no significant $(P>0.05)$ effect on feed consumption, day egg production of hen, egg weight and feed conversion.

Results on Table 3 show that the feed intake levels obtained during the study with fermented kapok seed ranged from $556.30 \mathrm{~g} / \mathrm{head} / \mathrm{week}$ to 569.05 $\mathrm{g} /$ head/week or ranged from $79.47 \mathrm{~g} / \mathrm{head} /$ day to $81.29 \mathrm{~g} / \mathrm{head} /$ day. Average feed intake in this study was lower than 90-100 g/head/day reported by Nurtini [12] and $88 \mathrm{~g} / \mathrm{head} /$ day by Cresswell and Gunawan [13]. According to Murtijo [14], feed consumption of laying hen aged 25-70 weeks is $115 \mathrm{~g} / \mathrm{head} /$ day.

No significant difference of feed consumption was due to that kapok seed has been fermented appropriately, and hence improves their quality and gives palatability similar to soybean meal. Consequently, the use of fermented kapok seed up to $29.35 \%$ in the ration of laying hen, equal to $100 \%$ soybean meal substitution, had no effect on feed intake. Moreover, no significant effect on feed consumption was also due to the nutrient content of metabolizable energy, protein and other nutrients similar in each treatment.

Effect of treatment on day egg production of hen during the study presented in Table 3 shows also no significant effect among the different treatments $(P>$ 

on Production and Egg Quality from Native Laying Hens

0.05). This is due to that the feed conversion, protein and energy content of the ration (17\% and 2,800 $\mathrm{kcal} / \mathrm{kg}$ ) as well as other food substances are relatively common and are in accordance with the needs of laying hens, so that it will produce the same egg production as well, in addition to the same maintenance and management of the environment. Iskandar et al. [15] state that the factors affecting egg production are genetic factor, management and feeding ration. In addition to the good quality ration, which affect egg production are the age factor, maintenance, environment, management, diseases and the amount of food [16].

In general, day egg production of hen generated in this study ranged from $32.38 \%$ to $34.09 \%$, or an average of $33.235 \%$, lower when compared with the results of Kingston [17], in which the day egg production of hen of native layer in Indonesia is $41.3 \%$. Low day production of hen is due to a genetic trait owned by a chicken that is not every day the chickens produce eggs. According to Kingston [17], it was proposed that egg production is influenced by genetic factors, management and feeding. In addition to genetic factors, egg production was also influenced by the content of substances consumed, especially protein, energy, methionine, lysine, calcium and phosphorus in the ration.

Utilization of fermented kapok seed in native layer ration up to $29.35 \%$ or $100 \%$ substitution of soybean meal protein can be done with a production of about $33.36 \%$. Although production at $\mathrm{R}_{5}$ only $32.38 \%$, but with a relatively low cost of the ration compared with other treatments, will produce a considerable profit. This is due to the processing of fermented kapok seed can improve the quality of the kapok seeds, thus then will affect the quality of rations and eventually can maintain egg production. According to Rasyaf [18], fermented kapok seed can not be fed to native layer more than $20 \%$ in the diet, because the fermented kapok seed can be supplied in the diet as much as $29.35 \%$ or $100 \%$ replacement protein soybean meal without affecting production and provide greater profits.

The average weight of chicken eggs ranged from $96.48 \mathrm{~g} /$ head/week to $102.23 \mathrm{~g} /$ head/week or 37.70 g/egg to $38.94 \mathrm{~g} /$ egg (Table 3). This result is slightly lower than that reported by Iskandar et al. [15], who showed that the weight of chicken eggs intensively rearched at $41 \mathrm{~g} / \mathrm{egg}$, but not much different from 39.96 g/egg reported by Murtidjo [14].

The weight of the eggs produced in this study was not much influenced by the level of soybean meal protein substitution with fermented kapok seed. This situation is caused by the consumption of feed, energy and protein content of the ration, as well as other food substances that are relatively the same for each treatment and the processing of kapok seed. According to Romanof, A. L. and Romanof, A. J. [19], the level of protein in the diet has a major influence on egg weight. The decline in energy and protein consumption can lead to a decrease in egg weight [20]. Weight and size of eggs are also influenced by the content of methionine, lysine, calcium and phosphorus in the ration. The ration content of $0.293 \mathrm{~g} / \mathrm{head} / \mathrm{day}$ methionine and $0.99 \mathrm{~g} / \mathrm{head} / \mathrm{day}$ lysine is able to produce normal eggs in terms of weight and size. The need of calcium to produce large eggs normally is $3.7 \%$ for 40 -week-old layer hen and $0.353 \%$ phosphorus [21]. Methionine consumption in this study amounted to $0.23 \mathrm{~g} / \mathrm{head} /$ day and lysine was $0.68 \mathrm{~g} / \mathrm{head} /$ day to $0.88 \mathrm{~g} / \mathrm{head} /$ day.

The average feed conversion during the study ranged between 5.33 and 5.61 (Table 3). Results of analysis of variance showed that among the treatments there was no significant effect $(P>0.05)$. Weight of eggs is produced in according with the feed intake and feed conversion ratio of the amount of feed consumed. This situation indicates that the rate of substitution of soybean meal to $100 \%$ with fermented kapok seeds with a mold Trichoderma harzianum for $8 \mathrm{~d}$ with a temperature of $30{ }^{\circ} \mathrm{C}$ can increase the use of ration and in turn will result in the conversion rate relatively the same to control diet. 
Table 4 Effect of treatment of eggshell thickness, score yellow egg and income over feed cost.

\begin{tabular}{llll}
\hline Treatments & $\begin{array}{l}\text { Eggshell thickness } \\
(\mathrm{mm})\end{array}$ & Score color yellow eggs & $\begin{array}{l}\text { Income over } \\
\text { feed cost (Rp) }\end{array}$ \\
\hline $\mathrm{R}_{0}$ & 0.30 & 8.46 & $3,819.72$ \\
$\mathrm{R}_{\mathrm{l}}$ & 0.29 & 852 & $4,149.00$ \\
$\mathrm{R}_{2}$ & 0.30 & 8.97 & $4,350.12$ \\
$\mathrm{R}_{3}$ & 0.30 & 9.02 & $4,534.20$ \\
$\mathrm{R}_{4}$ & 0.29 & 9.14 & $4,719.72$ \\
$\mathrm{R}_{5}$ & 0.28 & 9.03 & $4,816.04$ \\
\hline Average & 0.29 & 8.86 & $4,397.63$ \\
\hline
\end{tabular}

3.2 Effect of the Treatment on Eggshell Thickness, Yellow Egg and Income over Feed Cost

The average thickness of egg shell, yolk color score and income over feed cost can be seen in Table 4.

The mean thickness of egg shell and yolk color score ranged from $0.28 \mathrm{~mm}$ to $0.30 \mathrm{~mm}$ and from 8.46 to 9.14, respectively. Results of analysis of variance on eggshell thickness variables showed that among the treatments there was no significant effect $(P>0.05)$. This is caused by that the content of calcium (ranging between 2.88\% and 3.03\%) and phosphorus (ranging between $0.66 \%$ and $0.73 \%$ ) in ration is similar. This is consistent with that recommended by National Research Council (NRC) [16]. Eggshell thickness in this study was same as that recommended by Stadelman and Cotterrill [22]. The thickness and color of the eggshell is caused by pigment ovoporphirin deposited on the surface of the egg with a thickness less than $0.33 \mathrm{~mm}$. According to Murtidjo [14], eggshell thickness less than $0.31 \mathrm{~mm}$ is too thin to be marketed, while the eggs are good to have a thickness of about $0.29 \mathrm{~mm}$.

The yellow color of the eggs produced in this study varies from yellow to orange with yellow egg scores ranging from 8.46 to 9.14. According to Nurtini [12], consumers generally like golden color egg yolk that gives the attractive appearance to stimulate appetite or interest. The intensity of the color of egg yolk in birds is determined by the consumption of carotenoid pigments [19]. Anggorodi [23] stated that lutein, zeaxanti and criptoxantin were responsible for the pigmentation of egg yolk color and the addition of xanthophylls in poultry feed can increase egg yolk color score.

The average income in this study is presented in Table 4. The advantage gained during the study ranged from $\mathrm{Rp} 3,819.72$ to $\mathrm{Rp} 4,816.04$ or $\mathrm{Rp}$ 180.33/egg to Rp 235.28/egg. It can be seen that the profits increase with the increasing use of fermented kapok seed in the ration. This is due to the fermented kapok seed cost less than soybean meal.

\section{Conclusions}

The use of fermented kapok seed fermentation in native laying hen rations had no significant effects on the production performance of layers, mainly on feed intake, feed conversion and egg production. Substitution of soybean meal protein with fermented kapok seed in the ration can be up to $100 \%$ in the diet of native laying hens.

\section{References}

[1] Central Bureau of Statistics (BPS). 2013. "Statistics Indonesia.” Accessed October 8, 2013. http://www.datastatistik-indonesia.com/proyeksi/index.php ?option=com_content\&task=view\&id=910\&Itemid=923.

[2] Andalas University. 2013. Poultry Laboratory Research Result, Faculty of Animal Husbandry, Andalas University in Padang Limau Manis.

[3] Zahirma, U. 1986. "Analysis of Acid Siklopropenoat from Kapok Seed with Gas Chromatography Techniques.” Bachelor thesis, Faculty of Mathematics, University of Indonesia, Jakarta.

[4] Sihombing, D. T. H. 1974. "Effect of Bungkil Castor Bean and Bungkil Kapok Bean against Broilers.” Bachelor thesis, Faculty of Animal Husbandry, Bogor Agricultural University.

[5] Sahid, M., Budi, S., Mukoni, H. J., and Buadi, R. 2000. 

on Production and Egg Quality from Native Laying Hens

"Diversification of the Results, the Main Processing and Cotton Crop Byproducts.” In Proceedings of the Meeting of the Commission for Agricultural Research Field Plantation, 220-7.

[6] Lauw, T. G., Samsudin, M. D., Husaini, B. S., and Ignatius Tarwotjo, M. S. 1967. "Nutritional Value of Kapok Seed Protein.” American Journal of Clinical Nutrition 20 (12): 1300-3.

[7] Syahruddin, E., and Herawaty, R. 2009. Giving Kapok Seeds Fermented with Neurosphora sitophyla against Performance. Broiler Research Report, Faculty of Animal Husbandry, Andalas University, Padang.

[8] Toh, K. S., and Chia, S. K. 1977. "Nutritional Value of Rubber Seed Meal in the Live Stock in Southeast Asia." In Feeding Stuff for Livestock in Southeast Asia, edited by Devendra, C., and Hutagalung, R. I. Malaysia: Malaysian Society of Animal Production, 345-51.

[9] Syahruddin, E., and Herawaty, R. 2010. Giving Fresh Kapok Seed against Performance. Broiler Research Report, Faculty of Animal Husbandry, Andalas University, Padang.

[10] Chalal, D. S. 1985. "Solid State Fermentation with Trichoderma resel for Cellulose Production.” Appl. Environ. Microbial. 49 (1): 205-10.

[11] Steel, R. G. D., and Torrie, J. H. 2013. Principles and Procedures of Statistics: An Approach. Singapore: Mc Grow Hill International Book Company.

[12] Nurtini, S. 1988. "Ranch Business Overview and Prospects Poultry Laying.” Presented at National Seminar of Miscellaneous Livestock Poultry II, Balitnak-Bogor.

[13] Cresswell, D. C., and Gunawan, B. 1982. Indigenous
Chickens in Indonesia: Production Characteristics in an Improved Environment. Report No. 2, Research Institute for Animal Production, Bogor, Indonesia.

[14] Murtidjo, M. 1992. Managing Domestic Poultry. Yogyakarta: Canisius Publisher.

[15] Elizabeth, I., Desmayati, Z., Heti, R., Broto, W., and Sumanto. 1991. Appropriate Technology of Native Chicken. Bogor: Livestock Research Center.

[16] National Research Council (NRC). 1994. Nutrient Requirements of Poultry, 9th ed.. Washington, DC: National Academy of Science.

[17] Kingston, D. 1979. "The Role of Chicken Wandering Indonesia.” Presented at the II Seminar on Science and Poultry Industry, Livestock Research and Development Center, Bogor.

[18] Rasyaf, M. 2004. Food Chicken. Yogyakarta: Canisius Prints, 120-2.

[19] Romanoff, A. L., and Romanoff, A. J. 1983. The Avian Egg, 2nd ed.. Westport: John Willey and Son Inc..

[20] Balnave, D., Yoselewitz, I., and Dixon, R. J. 1989. "Physiological Changes Associated with the Production of Defective Eggshells by Hens Receiving Sodium Chloride in the Drinking Water." British Journal of Nutrition 61: 35-43.

[21] Wahju, J. 1992. Poultry Nutrition. Bogor: Gajah Mada University Press.

[22] Stadelman, W. J., and Cotterill, O. J. 1997. Egg Science and Technology, 2nd Ed. Westport, Connecticut: Avan. Pub. C. Inc..

[23] Anggorodi, R. 1985. Science Fodder General. Jakarta: Gramedi Publisher. 